\title{
Effects of Sarcopenic Obesity on Metabolic Syndrome in Korean Elders: Using Data from the Korea National Health and Nutrition Examination Survey (2008-2011)
}

\author{
Choi, Hyun-A ${ }^{1} \cdot$ Park, Kyung-Min ${ }^{2}$ \\ ${ }^{1}$ Department of Nursing, Sunlin University, Pohang \\ ${ }^{2}$ College of Nursing, Keimyung University, Daegu, Korea
}

Purpose: This study was conducted to examine effects of sarcopenic obesity on metabolic syndrome in Korean elders. Methods: This study is based on the analysis of the Korea National Health and Nutrition Examination Survey (KNHANES) with 1,155 subjects (524 men, and 631 women) aged 60 or older, from 2008 to 2011. Sarcopenia was defined as an appendicular skeletal muscle (ASM), divided by weight (\%) of $<1$ SD (standard deviation) below the sex-specific mean for young adults. Obesity was defined as a total body fat percent (men $\geq 25 \%$, women $\geq 35 \%$ ). Results: The prevalence of SO (sarcopenic obesity) was $13.3 \%$ among men and $22.5 \%$ among women. Both sexes showed a higher total body fat percent, and the SMI (skeletal muscle index) was the lowest in the SO group. Metabolic syndrome was highly prevalent in the SO group (52.5\% men, $60.4 \%$ women). The SO group showed a higher risk for metabolic syndrome (odds ratio men 6.57 [95\% Cl 5.19 7.27], women 3.89 [95\% Cl 2.41 6.29]) than the obese group (men 3.14 [95\% Cl 1.76 4.14], women 2.54 [95\% Cl 1.38 4.65]). Conclusion: SO is a major risk factor for metabolic syndrome in Korean elders. Therefore, a nursing program should be given to the Korean elderly SO group to prevent metabolic syndrome.

Key Words: Sarcopenia, Obesity, Metabolism, Syndrome

\section{INTRODUCTION}

\section{Necessity of Study}

Recently, Korea has experienced rapid ageing of population because of decreased birth rate and prolonged average lifespan, and obese population continuously increases because of reduced physical activities resulted from westernized diet and transportation development [1]. According to National Statistical Office, obesity prevalence of adults over 19 in Korea was 30.9\% in 2014 and it has been maintained at the level of $31 \sim 32 \%$ for recent 7 years. Elderlies over 60 occupy $34.3 \%$ of obese population, which is higher than in whole adult population [2]. The phenomenon is not unique to Korea but other developed countries also experience it. It is perceived as an important health and social issue [3].
According to normal ageing process, male and female elderlies have changes in body composition such as increased fat mass (FM) and decreased muscle amount $[4,5]$. As people get old, abdominal visceral fat increases and subcutaneous fat decreases [6], which is known to be independent to change in body mass index (BMI) [7]. Accordingly elderlies with low BMI can have abdominal obesity unlike general adult population. Thus, sarcopenic obesity reflecting changes in body composition is proposed as a new obesity concept [6]. Sarcopenic obesity is combination of sarcopenia and obesity meaning the status with low amount of muscles and relatively high body mass [8].

Generally speaking, muscle amount gradually decreases from the age of 30 and the decrease is accelerated after 60 . It is known that body mass reaches peak approximately 60 to 75 [8]. Looking into prevalence of sarcopenic

\footnotetext{
Corresponding author: Park, Kyung-Min

College of Nursing, Keimyung University, 1095 Dalgubeol-daero, Dalseo-gu, Daegu 42601, Korea.

Tel: +82-53-580-3900, Fax: +82-53-580-3916, E-mail: kmp@kmu.ac.kr

Received: Jul 11, 2016 / Revised: Sep 3, 2016 / Accepted: Sep 3, 2016

This is an open access article distributed under the terms of the Creative Commons Attribution Non-Commercial License (http://creativecommons.org/licenses/ by-nc/3.0), which permits unrestricted non-commercial use, distribution, and reproduction in any medium, provided the original work is properly cited.
} 
obesity, diverse prevalence ( $0 \sim 48 \%)$ was found in large scale studies on local community elderlies [9]. In the study on elderlies over 60 in Korea, males and females showed $15.4 \%$ and $22.3 \%$ prevalence respectively [6]. Although study result is not consistent because of difference in diagnosis standards and cut off, old age and female were the variables to make prevalence higher [9]. Considering increase of aged population in Korea, it is thought not to be overlooked.

Ageing related sarcopenia means decrease in appendicular skeletal muscle mass and is not related to smooth muscle [4]. Recently, some researchers use it as a concept including muscle weakness. However, in this study it is limited to decrease in skeletal muscle amount, as reports on the relationship between muscle amount and muscle strength are not consistent [10].

The mechanism that muscle amount decreases with age is known to be because of changes in nervous system and hormone, deficiency in protein intake, decrease in muscle cells and imbalance between protein decomposition and composition [11]. Decrease in muscle amount reduces basal metabolic rate (BMR), increases body mass, and debases various physical functions [1]. Besides, skeletal muscle is primary tissue responsible for insulin-mediated glucose disposal and it is known that skeletal muscle decrease make influence on insulin resistance separately from obesity [12]. Additionally, body mass increase triggers insulin resistance by secreting inflammation including cytokine such as interleukin-6 and tumor necrosis factor-alpha, promotes decomposition of myofibrillar protein, reduces protein composition and consequently promotes muscle consumption [13]. As such body mass increase and muscle amount decrease are connected as a vicious circle so it is reported that the presence of both symptoms increases risk of dysfunction and metabolism disorder higher than the presence of either of sarcopenia or obesity $[1,7]$.

When looking into previous studies on the effects of sarcopenic obesity on health, it is reported that sarcopenic obesity degrades body functions, increases risk of disability $[7,14]$, increases risk of fall [16] by acting as a fragility risk factor [15], increases risk of metabolic syndrome and cardiovascular disorders $[3,12,17]$, increases death rate causing long-term hospitalization [18] and degrades quality of life [15]. Accordingly, western countries, especially USA, have made active researches on epidemiology, prevention and management strategy of sarcopenic obesity [16], but in Asia including Korea researches on sarcopenic obesity still remain in early stage and its importance has not been recognized yet. Especially it is known that sarcopenia and obesity interact and increase risk factors of metabolic syndrome, which is the state where abdominal obesity, high blood pressure and hyperglycemia are combined. It is very important issue that can increase risk of death as well as it is related with Type II diabetes and cardiovascular disorders [19]. Nevertheless, studies on sarcopenic obesity focused on researches related to physical disorders and although researches on metabolic syndrome have been made, they are not sufficiently made and results are inconsistent reporting relationship $[3,6,17]$ or no relationship $[7,20]$. Besides, Asians are known to have more visceral obesity than westerners even at the same BMI or waist measurement [21], it is thought necessary to perform a study on effects of sarcopenic obesity on metabolic syndrome with sample that can represent Korean elderlies. Additionally, studies on sex difference in sarcopenic obesity have not been made yet although it is thought that there is gender difference in the relationship between sarcopenic obesity and metabolic syndrome. In males, sex hormone testosterone decrease makes decisive effects on muscle size and muscle strength and is also related to abdominal obesity increase, insulin resistance increase and metabolic syndrome $[9,14,17]$, while in females estrogen decrease after menopause redistributes fat accumulated in hips and thighs to abdomen, decreases metabolism to have more abdomen fat than males and decreases total weight without fat $[15,20]$. Thus, we may develop more differentiated intervention strategy if we compare males and females and identify their differences and widen our understanding on sarcopenic obesity.

Accordingly, in this study materials from Korea National Health and Nutrition Examination Survey were used. It was tried to identify characteristics of sarcopenic obesity of males and females respectively and compare the effects of sarcopenia and obesity on metabolic syndrome according to gender. The study was performed to understand characteristics of male and female sarcopenic obesity subjects better and to use the study results as basic materials for prevention and management of metabolic syndrome considering those characteristics.

\section{Purpose of the Study}

This study classified elderlies over 60 as normal., obesity, sarcopenia, and sarcopenic obesity based on the materials of Korea National Health and Nutrition Examination Survey and identified difference in general and health related characteristics of each male and female group, physical composition and metabolism index, difference in prevalence of metabolic syndrome, and effects of sarco- 
penic obesity on metabolic syndrome. Detailed purposes of study are like the followings.

- To identify difference in demographical and health related characteristics according to presence of sarcopenia and obesity in males and females.

- To identify difference in physical composition the group and difference in average individual metabolism index according to presence of sarcopenia and obesity in males and females.

- To identify difference in individual metabolism index of the group and difference in prevalence of metabolic syndrome according to presence of sarcopenia and obesity in males and females.

- To understand effects of male and female sarcopenic obesity on metabolic syndrome.

\section{METHODS}

\section{Design}

This study is a sectional descriptive study to identify the effects of sarcopenic obesity on metabolic syndrome of male and female elderlies in communities using the materials of Korea National Health and Nutrition Examination Survey.

\section{Subjects}

This study used materials of Korea National Health and Nutrition Examination Survey from 2008 to 2011 by Korea Centers for Disease Control and Prevention which include bone density and body fat test. Korea National Health and Nutrition Examination Survey is designed to represent all households and citizens living in Korea by using multistage layering cluster sampling method but it excludes foreigners and Koreans in facilities such as asylums, military and jail. The Fourth Term Survey (2007 2009) used materials of 2005 National Statistical Office, and the Fifth Term Survey (2010 2012) used 2009 Residence Registration Population and 2008 Apartment Price as sampling frames. Additionally, from the fourth term, rolling survey sampling method was introduced to make a rolling sample of each year a probability sample representing the whole country, and best efforts were made to abstract independent and homogeneous samples for rolling samples [22].

From 2008 to 201137,753 people (17,195 males and 20,558 females) participated. In this study, the final subjects were screened as 1,155 people (524 males and 631 females) who were over 60 , were less than 8 hours' fasting, who did not have diabetes, malicious tumor, stroke, myocardial infarc- tion, angina, cirrhosis and heart failure and who did not have any missing values out of 21,303 people $(9,360$ males and 11,943 females) who finished health survey, completed bone density and body fat test.

\section{Tool}

\section{1) Demographical and health related characteristics vari- ables}

Demographical characteristics of subjects used as variables in this study were age, gender, income, education, and health related characteristics subjective health status, drinking, melancholy, smoking, strength training and walking practice rate. For income, income quartile (individual) proposed in Korea National Health and Nutrition Examination Survey was used. It is monthly average household equalized income and monthly household income is classified as high, mid-high, mid-low and low. For education, graduation was used as standard and materials classified as lower than elementary graduation, middle school graduation, high school graduation and higher than university graduation were used. Subjective health status is the health status that the subject himself or herself subjectively perceives his or her health. It is measured as 5 point scale from Very Bad (5) to Very Good (1). Higher point means worse health status. Alcohol drinking frequency was reclassified as None (Less than once a month), Occasionally (1 to 4 times per month), Frequently ( 2 to 3 times or more than 4 times a week), and to measure melancholy a questions asking if he or she had been melancholy more than 2 weeks in the previous year. For smoking, those who currently smoke were classified in Smoking group, those who quit smoking Past Smoking group and those who never smoked Nonsmoking group. For strength training, they were reclassified according to days of exercise as None, Once or twice per week and More than 3 days per week. For walking practice rate, materials classified as Yes and No if they had more than 30 minutes walking per time and more than 5 times per week.

\section{2) Physical composition and individual metabolism index materials}

For physical composition, height, weight, waist and BMI were used. For appendicular skeletal muscle mass (ASM) and total fat percent, bone density and body fat measured by dual energy $x$-ray absormetry (DEXA). DEXA measures body composition separating it as bone mineral content, body fat mass and lean body mass, and it has advantage to measure body composition by areas of the body. Among them, sum of muscle amount calculating by subtracting 
bone mineral content from lean body mass of limbs is ASM, which is a major index of sarcopenia [4]. From individual metabolism index data, systolic and diastolic blood pressure were measured three times at a steady state and average value was used for the study. For total cholesterol, high-density lipoprotein (HDL) cholesterol, neutral fat and fasting blood glucose, values from Hitachi Automatic Analyzer 7,600 (Hitachi/Japan) were used.

\section{3) Presence of Sarcopenia and Obesity}

To diagnose sarcopenia, a method proposed by Janssen et al. [23] and modified by Lim et al. [3] was used. This is the method calculating Skeletal Muscle Index (SMI= ASM/Wt $\times$ 100) by dividing ASM by weight. When the resultant SMI value decreased from average value of healthy and young group by less than 1 standard deviation (SD), it is defined as sarcopenia.

In this study, adults from 20 to 39 participating in Korea National Health and Nutrition Examination Survey at the same period, did not have malicious tumors, stroke, myocardial infarction, angina, cirrhosis, heart failure, diabetes, tuberculosis and asthma and had DEXA examination were used as healthy and young group. 2,292 males and 3,157 females were selected as healthy and young group and male and female SMI averages were calculated. Males and females who had SMI value decreased from the calculated value by less than 1 SD were Males $<30.52 \%$ and Females $<23.8 \%$.

For obesity, body fat rate measured by DEXA was used. It was selected based on previous studies reporting that body fat rate would be more appropriate for the standard of elderlies' obesity than BMI [7]. Based on previous studies, obesity was defined as over $25 \%$ for men and over $35 \%$ for women [24].

According to presence of sarcopenia and obesity, they were classified into 4 groups such as Normal (normal muscle amount, Non-obesity), obesity (normal muscle amount, obesity), sarcopenia (sarcopenia, Non-obesity) and sarcopenic obesity (sarcopenia, obesity) and made sure no redundancy made.

\section{4) Metabolic Syndrome}

Standards of National Cholesterol Education Program's Adult Treatment Panel III (Modified NCEP ATP III) proposed by the 2005 American Heart Association Conference. When they satisfied more than three out of the following five components, they were defined to have Metabolic Syndrome [25], and for waist size for abdominal obesity, Korean standard waist sizes proposed by Obesity Association were applied [26].
- When waist is over $90 \mathrm{~cm}$ (male) or over $85 \mathrm{~cm}$ (female)

- When systolic blood pressure is over $130 \mathrm{mmHg}$ or diastolic blood pressure over $85 \mathrm{mmHg}$ or administering antihypertensive agents

- When neutral fat is over $150 \mathrm{mg} / \mathrm{dL}$ or administering medications because of dyslipidemia

- HDL Cholesterol is under $40 \mathrm{mg} / \mathrm{dL}$ (male) or $50 \mathrm{mg} /$ $\mathrm{dL}$ (female)

- Fasting blood glucose is over $100 \mathrm{mg} / \mathrm{dL}$ or under the treatment using hypoglycemic agent or insulin

\section{Material Collection and Analysis Method}

From the fourth and fifth term Korea National Health and Nutrition Examination Survey by Korea Centers for Disease Control and Prevention, four years' materials such as from 2008 to 2011 were used. As raw materials are in public domain, we used them after getting official permission to use data through Korea National Health and Nutrition Examination Survey homepage.

We integrated them according to raw material analysis guidelines and weight of each survey division proposed by Korea National Health and Nutrition Examination Survey was used. For bone density and body fat test, integrated weight of the term was used. SPSS 20.0 program was used for analysis with designated composite sample design elements. Analysis results presented in this study are the results modified by weight variables. Differences in demographical, health related characteristics, physical composition and individual metabolism index were analyzed using average, standard deviation, $x^{2}$ test and ANOVA and post analysis was made through Scheffé'. In order to identify effects of sarcopenic obesity on metabolic syndrome logistic regression analysis was performed.

\section{RESULTS}

\section{Demographical and Health related Characteris- tics Difference according to the Presence of Sarcopenia and Obesity of Males and Females}

Out of total subjects of 1,155 Normal were 552 (290 males and 262 females), obesity 169 (59 males and 110 females), sarcopenia 30 (21 males and 9 females) and sarcopenic obesity 404 (154 males and 250 females). After applying weights, the values could be generalized as Normal 695,986 (361,874 males and 334,112 females), obesity 196,921 (65,336 males and 131,586 females), sarcopenia 42,859 (28,623 males and 14,236 females) and sarcopenic obesity 521,646 (193,590 males and 328,056 females). 


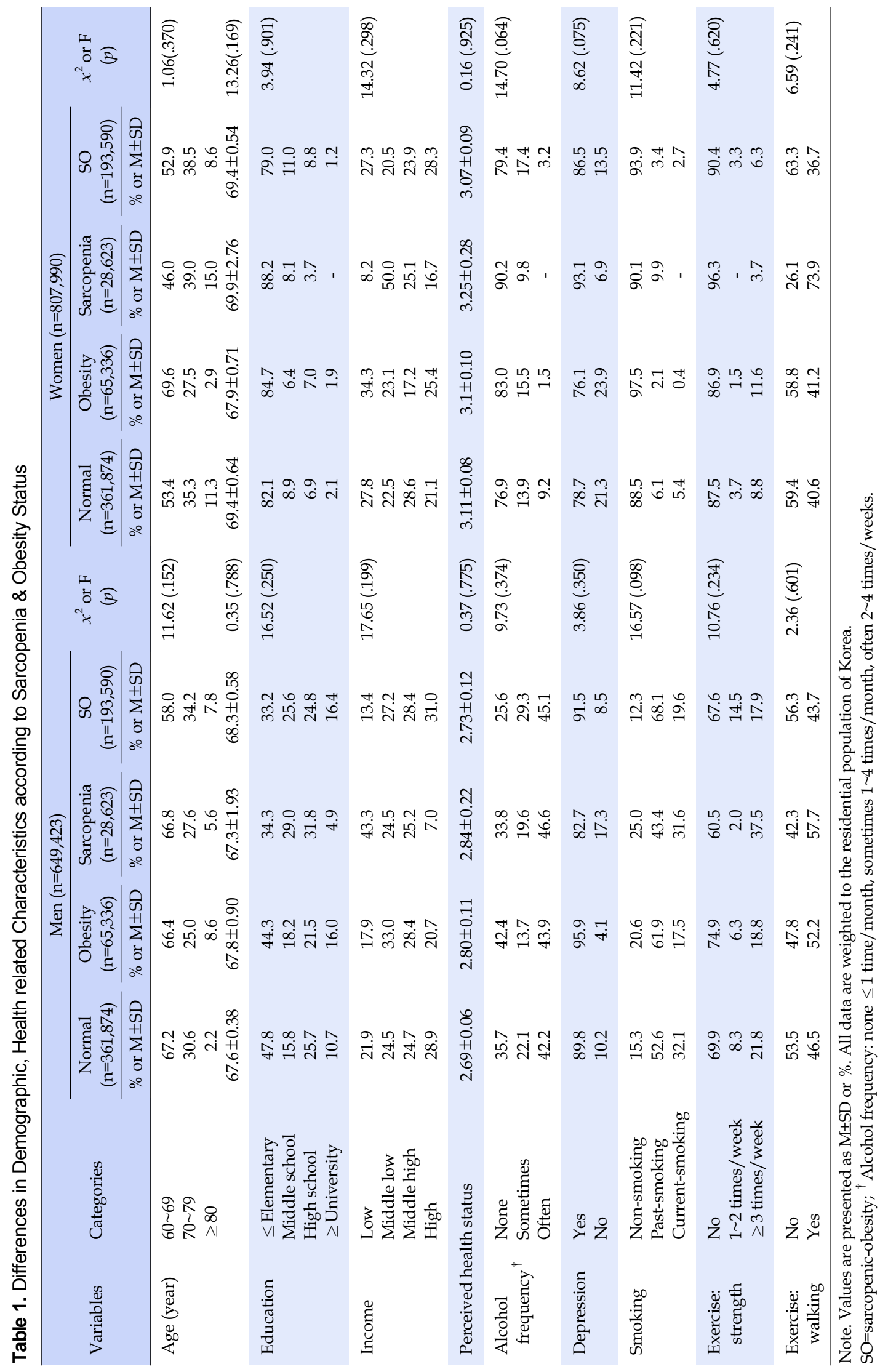


In Sarcopenic obesity group, males were $13.3 \%$ and females were $22.5 \%$, which are very high comparing to pure obesity (male $4.5 \%$ male and female $9.0 \%$ ) or pure sarcopenia (male $2.0 \%$ and female $0.9 \%$ ).

Demographical and health related characteristics of subjects were not significantly different in both males and females (Table 1).

\section{Difference in Physical Composition and Individual Metabolism Index according to the Presence of Male and Female Sarcopenia and Obesity}

The results comparing physical composition and individual metabolism index among groups are shown in
Table 2.

In the average of physical composition, males showed the highest total body fat rate and the lowest SMI (\%) in sarcopenic obesity group ( $\mathrm{F}=343.80, p<.001)$, which was statistically significant $(\mathrm{F}=213.10, p<.001)$. Females showed highest weight, waist size, BMI and total body fat rate in sarcopenic obesity group $(p<.001)$, SMI $(\%)$ was the lowest, and the difference was statistically significant $(\mathrm{F}=$ $234.61, p<.001)$.

In individual metabolism index, males showed lowest HDL Cholesterol in sarcopenic obesity group and the difference was statistically significant $(\mathrm{F}=4.33, p<.01)$ but HDL Cholesterol value itself $(42.48 \mathrm{mg} / \mathrm{dL})$ was in the range of normal values. In case of females, sarcopenic obesity group

Table 2. Differences in Body Composition and Metabolic Component according to Sarcopenia \& Obesity Status

\begin{tabular}{|c|c|c|c|c|c|c|c|c|c|c|}
\hline \multirow{3}{*}{ Variables } & \multicolumn{4}{|c|}{ Men $(n=649,423)$} & \multirow{3}{*}{$\begin{array}{c}x^{2} \text { or } \mathrm{F} \\
(p)\end{array}$} & \multicolumn{4}{|c|}{ Women $(\mathrm{n}=807,990)$} & \multirow{3}{*}{$\begin{array}{c}x^{2} \text { or } \mathrm{F} \\
(p)\end{array}$} \\
\hline & $\begin{array}{c}\text { Normal } \\
(\mathrm{n}=361,874)\end{array}$ & $\begin{array}{c}\text { Obesity } \\
(\mathrm{n}=65,336)\end{array}$ & $\begin{array}{l}\text { Sarcopenia } \\
(\mathrm{n}=28,623)\end{array}$ & $\begin{array}{c}\mathrm{SO} \\
(\mathrm{n}=193,590)\end{array}$ & & $\begin{array}{c}\text { Normal } \\
(\mathrm{n}=334,112)\end{array}$ & $\begin{array}{c}\text { Obesity } \\
(\mathrm{n}=131,586)\end{array}$ & $\begin{array}{l}\text { Sarcopenia } \\
(\mathrm{n}=14,236)\end{array}$ & $\begin{array}{c}\mathrm{SO} \\
(\mathrm{n}=328,056)\end{array}$ & \\
\hline & $\mathrm{M} \pm \mathrm{SD}$ & $\mathrm{M} \pm \mathrm{SD}$ & $\mathrm{M} \pm \mathrm{SD}$ & $\mathrm{M} \pm \mathrm{SD}$ & & $\mathrm{M} \pm \mathrm{SD}$ & $\mathrm{M} \pm \mathrm{SD}$ & $\mathrm{M} \pm \mathrm{SD}$ & $\mathrm{M} \pm \mathrm{SD}$ & \\
\hline Height $(\mathrm{cm})$ & $\begin{array}{l}165.6 \\
\pm 0.35\end{array}$ & $\begin{array}{l}165.8 \\
\pm 0.90\end{array}$ & $\begin{array}{l}167.0 \\
\pm 1.35\end{array}$ & $\begin{array}{l}165.1 \\
\pm 0.52\end{array}$ & $\begin{array}{c}0.78 \\
(.509)\end{array}$ & $\begin{array}{l}151.9 \\
\pm 0.44\end{array}$ & $\begin{array}{l}152.7 \\
\pm 0.51\end{array}$ & $\begin{array}{l}148.7 \\
\pm 2.16\end{array}$ & $\begin{array}{l}151.7 \\
\pm 0.44\end{array}$ & $\begin{array}{l}1.47 \\
(.227)\end{array}$ \\
\hline Weight $(\mathrm{kg})$ & $\begin{array}{l}61.0^{\mathrm{a}} \\
\pm 0.57\end{array}$ & $\begin{array}{l}69.3^{\mathrm{b}} \\
\pm 1.42\end{array}$ & $\begin{array}{l}63.3^{\mathrm{a}} \\
\pm 1.98\end{array}$ & $\begin{array}{l}69.2^{\mathrm{b}} \\
\pm 0.75\end{array}$ & $\begin{array}{c}24.69 \\
(<.001)\end{array}$ & $\begin{array}{l}50.8^{\mathrm{a}} \\
\pm 0.50\end{array}$ & $\begin{array}{l}58.2^{\mathrm{b}} \\
\pm 0.76\end{array}$ & $\begin{array}{l}50.4^{\mathrm{a}} \\
\pm 2.27\end{array}$ & $\begin{array}{l}60.2^{\mathrm{b}} \\
\pm 0.61\end{array}$ & $\begin{array}{c}59.62 \\
(<.001)\end{array}$ \\
\hline $\begin{array}{l}\text { Waist } \\
\text { circumference } \\
(\mathrm{cm})\end{array}$ & $\begin{array}{l}81.28^{\mathrm{a}} \\
\pm 0.59\end{array}$ & $\begin{array}{l}89.31^{b} \\
\pm 1.17\end{array}$ & $\begin{array}{l}84.48^{\mathrm{a}} \\
\pm 1.60\end{array}$ & $\begin{array}{l}89.85^{\mathrm{b}} \\
\pm 0.75\end{array}$ & $\begin{array}{c}30.51 \\
(<.001)\end{array}$ & $\begin{array}{l}77.10^{\mathrm{a}} \\
\pm 0.57\end{array}$ & $\begin{array}{l}84.94^{\mathrm{b}} \\
\pm 0.78\end{array}$ & $\begin{array}{l}80.03^{\mathrm{a}} \\
\pm 2.93\end{array}$ & $\begin{array}{l}87.64^{c} \\
\pm 0.55\end{array}$ & $\begin{array}{c}65.92 \\
(<.001)\end{array}$ \\
\hline $\begin{array}{l}\text { Body mass index } \\
\left(\mathrm{BMI}, \mathrm{kg} / \mathrm{m}^{2}\right)\end{array}$ & $\begin{array}{l}22.17^{\mathrm{a}} \\
\pm 0.18\end{array}$ & $\begin{array}{l}25.13^{\mathrm{b}} \\
\pm 0.35\end{array}$ & $\begin{array}{l}22.65^{\mathrm{a}} \\
\pm 0.53\end{array}$ & $\begin{array}{l}25.38^{\mathrm{b}} \\
\pm 0.27\end{array}$ & $\begin{array}{c}39.53 \\
(<.001)\end{array}$ & $\begin{array}{l}21.97^{\mathrm{a}} \\
\pm 0.16\end{array}$ & $\begin{array}{l}24.95^{\mathrm{b}} \\
\pm 0.30\end{array}$ & $\begin{array}{l}22.74^{\mathrm{a}} \\
\pm 0.70\end{array}$ & $\begin{array}{l}26.12^{c} \\
\pm 0.24\end{array}$ & $\begin{array}{c}86.05 \\
(<.001)\end{array}$ \\
\hline ASM (kg) & $\begin{array}{l}20.24^{\mathrm{b}} \\
\pm 0.21\end{array}$ & $\begin{array}{l}21.52^{c} \\
\pm 0.44\end{array}$ & $\begin{array}{l}18.74^{\mathrm{a}} \\
\pm 0.67\end{array}$ & $\begin{array}{l}19.53^{\mathrm{a}} \\
\pm 0.20\end{array}$ & $\begin{array}{c}8.31 \\
(<.001)\end{array}$ & $\begin{array}{l}13.65^{\mathrm{c}} \\
\pm 0.15\end{array}$ & $\begin{array}{l}14.27^{\mathrm{d}} \\
\pm 0.20\end{array}$ & $\begin{array}{l}11.69^{\mathrm{a}} \\
\pm 0.55\end{array}$ & $\begin{array}{l}13.16^{\mathrm{b}} \\
\pm 0.14\end{array}$ & $\begin{array}{c}13.56 \\
(<.001)\end{array}$ \\
\hline $\begin{array}{c}\text { Skeletal muscle } \\
\text { index (SMI\%) }\end{array}$ & $\begin{array}{l}33.52^{\mathrm{d}} \\
\pm 0.14\end{array}$ & $\begin{array}{l}31.23^{\mathrm{c}} \\
\pm 0.08\end{array}$ & $\begin{array}{l}29.81^{\mathrm{b}} \\
\pm 0.23\end{array}$ & $\begin{array}{l}28.44^{\mathrm{a}} \\
\pm 0.15\end{array}$ & $\begin{array}{c}213.10 \\
(<.001)\end{array}$ & $\begin{array}{l}27.17^{\mathrm{d}} \\
\pm 0.18\end{array}$ & $\begin{array}{l}24.74^{\mathrm{c}} \\
\pm 0.08\end{array}$ & $\begin{array}{l}23.40^{\mathrm{b}} \\
\pm 0.12\end{array}$ & $\begin{array}{l}22.05^{\mathrm{a}} \\
\pm 0.12\end{array}$ & $\begin{array}{c}234.61 \\
(<.001)\end{array}$ \\
\hline $\begin{array}{l}\text { Total body fat } \\
(\%)\end{array}$ & $\begin{array}{l}19.33^{\mathrm{a}} \\
\pm 0.24\end{array}$ & $\begin{array}{l}26.61^{c} \\
\pm 0.14\end{array}$ & $\begin{array}{l}23.43^{\mathrm{b}} \\
\pm 0.25\end{array}$ & $\begin{array}{l}29.22^{\mathrm{d}} \\
\pm 0.29\end{array}$ & $\begin{array}{l}343.80 \\
(<.001)\end{array}$ & $\begin{array}{l}29.92^{\mathrm{a}} \\
\pm 0.36\end{array}$ & $\begin{array}{l}37.02^{c} \\
\pm 0.12\end{array}$ & $\begin{array}{l}33.00^{\mathrm{b}} \\
\pm 0.55\end{array}$ & $\begin{array}{l}40.27^{\mathrm{d}} \\
\pm 0.26\end{array}$ & $\begin{array}{c}181.07 \\
(<.001)\end{array}$ \\
\hline $\begin{array}{l}\text { Systolic BP } \\
\text { (mmHg) }\end{array}$ & $\begin{array}{r}126.22 \\
\pm 1.50\end{array}$ & $\begin{array}{r}128.85 \\
\pm 2.98\end{array}$ & $\begin{array}{c}136.11 \\
\pm 6.18\end{array}$ & $\begin{array}{l}129.80 \\
\pm 1.49\end{array}$ & $\begin{array}{c}1.53 \\
(.210)\end{array}$ & $\begin{array}{r}129.88^{\mathrm{a}} \\
\pm 1.43\end{array}$ & $\begin{array}{c}132.59^{\mathrm{ab}} \\
\pm 2.72\end{array}$ & $\begin{array}{c}138.90^{\mathrm{ab}} \\
\pm 8.15\end{array}$ & $\begin{array}{c}134.11^{\mathrm{b}} \\
\pm 1.02\end{array}$ & $\begin{array}{c}2.87 \\
(<.05)\end{array}$ \\
\hline $\begin{array}{l}\text { Diastolic BP } \\
(\mathrm{mmHg})\end{array}$ & $\begin{array}{l}74.42^{\mathrm{a}} \\
\pm 0.73\end{array}$ & $\begin{array}{l}78.58^{\mathrm{b}} \\
\pm 1.40\end{array}$ & $\begin{array}{c}83.82^{\mathrm{ab}} \\
\pm 5.33\end{array}$ & $\begin{array}{c}76.21^{\mathrm{ab}} \\
\pm 1.11\end{array}$ & $\begin{array}{c}3.23 \\
(<.05)\end{array}$ & $\begin{array}{l}74.29 \\
\pm 0.77\end{array}$ & $\begin{array}{l}75.75 \\
\pm 1.30\end{array}$ & $\begin{array}{l}77.07 \\
\pm 3.50\end{array}$ & $\begin{array}{l}76.85 \\
\pm 0.62\end{array}$ & $\begin{array}{c}2.51 \\
(.062)\end{array}$ \\
\hline FPG (mg/dL) & $\begin{array}{l}97.41 \\
\pm 1.31\end{array}$ & $\begin{array}{l}98.39 \\
\pm 1.60\end{array}$ & $\begin{array}{l}99.46 \\
\pm 2.50\end{array}$ & $\begin{array}{l}103.46 \\
\pm 2.23\end{array}$ & $\begin{array}{c}1.83 \\
(.146)\end{array}$ & $\begin{array}{l}94.11^{\mathrm{a}} \\
\pm 0.81\end{array}$ & $\begin{array}{l}96.67^{\mathrm{b}} \\
\pm 1.09\end{array}$ & $\begin{array}{l}99.56^{\mathrm{ab}} \\
\pm 4.27\end{array}$ & $\begin{array}{l}97.86^{\mathrm{b}} \\
\pm 1.21\end{array}$ & $\begin{array}{c}3.04 \\
(<.05)\end{array}$ \\
\hline $\begin{array}{l}\text { Total cholesterol } \\
(\mathrm{mg} / \mathrm{dL})\end{array}$ & $\begin{array}{r}184.35 \\
\pm 2.40\end{array}$ & $\begin{array}{c}184.34 \\
\pm 3.88\end{array}$ & $\begin{array}{r}188.41 \\
\pm 6.39\end{array}$ & $\begin{array}{c}186.84 \\
\pm 3.57\end{array}$ & $\begin{array}{c}0.22 \\
(.881)\end{array}$ & $\begin{array}{r}198.48^{\mathrm{a}} \\
\pm 2.61\end{array}$ & $\begin{array}{r}198.40^{\mathrm{a}} \\
\pm 3.78\end{array}$ & $\begin{array}{l}184.96^{\mathrm{a}} \\
\pm 10.66\end{array}$ & $\begin{array}{l}209.14^{\mathrm{b}} \\
\pm 2.66\end{array}$ & $\begin{array}{l}3.58 \\
(<.05)\end{array}$ \\
\hline $\begin{array}{l}\text { HDL-cholesterol } \\
(\mathrm{mg} / \mathrm{dL})\end{array}$ & $\begin{array}{l}48.31^{\mathrm{b}} \\
\pm 0.70\end{array}$ & $\begin{array}{l}44.89^{\mathrm{ab}} \\
\pm 1.87\end{array}$ & $\begin{array}{l}48.18^{\mathrm{ab}} \\
\pm 4.02\end{array}$ & $\begin{array}{l}42.48^{\mathrm{a}} \\
\pm 1.35\end{array}$ & $\begin{array}{c}4.33 \\
(<.01)\end{array}$ & $\begin{array}{l}48.26^{\mathrm{b}} \\
\pm 0.65\end{array}$ & $\begin{array}{l}48.47^{\mathrm{b}} \\
\pm 1.08\end{array}$ & $\begin{array}{l}52.41^{\mathrm{ab}} \\
\pm 5.78\end{array}$ & $\begin{array}{l}45.77^{\mathrm{a}} \\
\pm 0.75\end{array}$ & $\begin{array}{c}2.93 \\
(<.05)\end{array}$ \\
\hline $\begin{array}{l}\text { Triglyceride } \\
(\mathrm{mg} / \mathrm{dL})\end{array}$ & $\begin{array}{r}125.30^{\mathrm{a}} \\
\pm 5.42\end{array}$ & $\begin{array}{l}155.83^{\mathrm{b}} \\
\pm 11.14\end{array}$ & $\begin{array}{c}153.59^{\mathrm{ab}} \\
\pm 24.01\end{array}$ & $\begin{array}{r}157.24^{\mathrm{b}} \\
\pm 8.48\end{array}$ & $\begin{array}{c}4.04 \\
(<.01)\end{array}$ & $\begin{array}{r}126.59^{\mathrm{a}} \\
\pm 6.04\end{array}$ & $\begin{array}{c}133.71^{\mathrm{a}} \\
\pm 9.40\end{array}$ & $\begin{array}{l}120.10^{\mathrm{a}} \\
\pm 15.36\end{array}$ & $\begin{array}{c}157.41^{\mathrm{b}} \\
\pm 7.78\end{array}$ & $\begin{array}{l}3.58 \\
(<.05)\end{array}$ \\
\hline
\end{tabular}

Note. Values are presented as $\mathrm{M} \pm \mathrm{SD}$. All data are weighted to the residential population of Korea.

$\mathrm{SO}=$ sarcopenic-obesity; ASM (kg)=appendicular skeletal muscle mass; FPG=fasting plasma glucose; HDL=high-density lipoprotein; post-hoc analysis: $\mathrm{a}<\mathrm{b}<\mathrm{c}<\mathrm{d}$. 
showed the highest systolic blood pressure, fasting blood glucose, total Cholesterol and neutral fat $(p<.05)$, and the lowest HDL Cholesterol $(\mathrm{F}=2.93, p<.05)$. However, fasting blood glucose of females $(97.86 \mathrm{mg} / \mathrm{dL})$ was in the range of normal values.

\section{Difference in Individual Metabolism Index and Prevalence of Metabolic Syndrome according to the Presence of Male and Female Sarcopenia and Obesity}

The results comparing individual metabolism index and prevalence of metabolic syndrome among groups are shown in Table 3.

In individual metabolism index, abdominal obesity was the highest in sarcopenic obesity in both males and females (male $51.1 \%$, female 61.8\%) $(p<.001)$ and females showed 10\% higher value than males. Additionally, males showed the highest value in Low HDL Cholesterol $\left(x^{2}=27.36, p<.01\right)$, and females hypertriglyceridemia $\left(x^{2}=13.75, p<.05\right)$ in sarcopenic obesity group and the difference was statistically significant. In case of males, hypertriglyceridemia was the highest in sarcopenia group $\left(x^{2}=19.29, p<.01\right)$. High blood pressure was the highest in obesity group in males $\left(x^{2}=17.04, p<.01\right)$, while it was highest in sarcopenia group in females $\left(x^{2}=14.59, p<.05\right)$.

In the prevalence of Metabolic Syndrome, males were in the order of sarcopenic obesity $(52.5 \%)$, obesity $(45.1 \%)$, sarcopenia (39.9\%) and normal $(24.2 \%)\left(x^{2}=38.26 p<.001\right)$, while females in the order of sarcopenic obesity $(60.4 \%)$, sarcopenia $(57.3 \%)$, obesity $(48.4 \%)$ and normal $(31.1 \%)$, and the difference was statistically significant $\left(x^{2}=45.52\right.$, $p<.001$ ). Especially, prevalence of Metabolic Syndrome among females was $7 \%$ higher than males.

\section{Effects of Male and Female Sarcopenic Obesity on Metabolic Syndrome}

The results of logistic regression analysis to verify effects of sarcopenic obesity on metabolic syndrome are shown in Table 4 . At the stage 1 age, at stage 2 age, smoking, drinking, exercise, and at stage 3 education and income were additionally adjusted.

In both males and females, obesity and sarcopenic obesity group showed higher probability of metabolic syndrome incidence than normal group. Male and female obesity groups showed 2.57 times (95\% CI: 1.22 5.38, $p<.05$ ) and 2.08 times (95\% CI: 1.12 3.88, $p<.05$ ) higher probability respectively and sarcopenic obesity groups showed 3.46 times (95\% CI: $2.11 \sim 5.65, p<.001)$ and 3.38 times (95\% CI: $2.19 \sim 5.21, p<.001$ ) higher probability. However, sarcopenia groups did not show statistically significant difference in both males and females. When age, smoking, drinking, exercise, education and income were adjusted (Model 3), probability of metabolic syndrome incidence in obesity group increased 3.14 times (95\% CI: 1.76 4.14, $p<.01$ ) and 2.54 times (95\% CI: 1.38 4.65, $p<.01$ ) respectively, which was higher than the values when only age was adjusted (Model 1). Sarcopenic obesity group showed higher probability of metabolic syndrome incidence in males and fe-

Table 3. Frequency of Metabolic Component and Metabolic Syndrome according to Sarcopenia \& Obesity Status

\begin{tabular}{|c|c|c|c|c|c|c|c|c|c|c|}
\hline \multirow{3}{*}{ Variables } & \multicolumn{4}{|c|}{ Men $(n=649,423)$} & \multirow{3}{*}{$x^{2}(p)$} & \multicolumn{4}{|c|}{ Women $(n=807,990)$} & \multirow{3}{*}{$x^{2}(p)$} \\
\hline & $\begin{array}{c}\text { Normal } \\
(n=361,874)\end{array}$ & $\begin{array}{c}\text { Obesity } \\
(\mathrm{n}=65,336)\end{array}$ & $\begin{array}{c}\text { Sarcopenia } \\
(n=28,623) \\
\end{array}$ & $\begin{array}{c}\mathrm{SO} \\
(\mathrm{n}=193,590)\end{array}$ & & $\begin{array}{c}\text { Normal } \\
(\mathrm{n}=334,112)\end{array}$ & $\begin{array}{c}\text { Obesity } \\
(\mathrm{n}=131,586)\end{array}$ & $\begin{array}{c}\text { Sarcopenia } \\
(\mathrm{n}=14,236)\end{array}$ & $\begin{array}{c}\mathrm{SO} \\
(\mathrm{n}=328,056)\end{array}$ & \\
\hline & $\%$ & $\%$ & $\%$ & $\%$ & & $\%$ & $\%$ & $\%$ & $\%$ & \\
\hline $\begin{array}{l}\text { Abdominal } \\
\text { obesity }\end{array}$ & 14.9 & 47.8 & 20.3 & 51.1 & $\begin{array}{c}75.84 \\
(<.001)\end{array}$ & 14.6 & 47.1 & 32.5 & 61.8 & $\begin{array}{l}123.88 \\
(<.001)\end{array}$ \\
\hline $\begin{array}{l}\text { High blood } \\
\text { pressure }\end{array}$ & 51.7 & 73.0 & 62.6 & 68.7 & $\begin{array}{l}17.04 \\
(<.01)\end{array}$ & 61.4 & 68.3 & 82.5 & 76.4 & $\begin{array}{l}14.59 \\
(<.05)\end{array}$ \\
\hline $\begin{array}{l}\text { Hyper- } \\
\text { triglyceridemia }\end{array}$ & 28.3 & 46.8 & 48.1 & 46.8 & $\begin{array}{l}19.29 \\
(<.01)\end{array}$ & 31.9 & 45.2 & 35.9 & 47.1 & $\begin{array}{l}13.75 \\
(<.05)\end{array}$ \\
\hline $\begin{array}{l}\text { Low HDL } \\
\text { cholesterolemia }\end{array}$ & 28.9 & 45.8 & 40.6 & 53.5 & $\begin{array}{l}27.36 \\
(<.01)\end{array}$ & 64.5 & 61.6 & 47.4 & 66.5 & $\begin{array}{c}2.24 \\
(.679)\end{array}$ \\
\hline $\begin{array}{l}\text { High fasting } \\
\text { plasma glucose }\end{array}$ & 31.8 & 36.9 & 46.0 & 44.0 & $\begin{array}{c}7.39 \\
(.188)\end{array}$ & 22.2 & 29.8 & 39.2 & 35.9 & $\begin{array}{l}12.30 \\
(.054)\end{array}$ \\
\hline $\begin{array}{l}\text { Metabolic } \\
\text { syndrome }\end{array}$ & 24.2 & 45.1 & 39.9 & 52.5 & $\begin{array}{c}38.26 \\
(<.001)\end{array}$ & 31.1 & 48.4 & 57.3 & 60.4 & $\begin{array}{c}45.52 \\
(<.001)\end{array}$ \\
\hline
\end{tabular}

Note. Values are presented as \%. All data are weighted to the residential population of Korea.

$\mathrm{SO}=$ sarcopenic-obesity; HDL=high-density lipoprotein. 
Table 4. Adjusted Odds Ratio Metabolic Syndrome according to Sarcopenia \& Obesity Status

\begin{tabular}{|c|c|c|c|c|c|c|c|c|}
\hline \multirow{4}{*}{ Variables } & \multicolumn{4}{|c|}{ Men } & \multicolumn{4}{|c|}{ Women } \\
\hline & Normal & Obesity & Sarcopenia & $\mathrm{SO}$ & Normal & Obesity & Sarcopenia & $\mathrm{SO}$ \\
\hline & OR $(95 \% \mathrm{CI})$ & OR $(95 \% \mathrm{CI})$ & OR $(95 \% \mathrm{CI})$ & OR $(95 \% \mathrm{CI})$ & OR $(95 \% \mathrm{CI})$ & OR $(95 \% \mathrm{CI})$ & OR $(95 \% \mathrm{CI})$ & OR $(95 \% \mathrm{CI})$ \\
\hline & $p$ & $p$ & $p$ & $p$ & $p$ & $p$ & $p$ & $p$ \\
\hline Unadjusted & 1.00 & $\begin{array}{c}2.57 \\
(1.22 \sim 5.38) \\
<.05\end{array}$ & $\begin{array}{c}2.07 \\
(0.61 \sim 6.98) \\
.238\end{array}$ & $\begin{array}{c}3.46 \\
(2.11 \sim 5.65) \\
<.001\end{array}$ & 1.00 & $\begin{array}{c}2.08 \\
(1.12 \sim 3.88) \\
<.05\end{array}$ & $\begin{array}{c}2.98 \\
(0.62 \sim 14.34) \\
.171\end{array}$ & $\begin{array}{c}3.38 \\
(2.19 \sim 5.21) \\
<.001\end{array}$ \\
\hline Model $1^{\dagger}$ & 1.00 & $\begin{array}{c}2.70 \\
(1.29 \sim 5.62) \\
<.01\end{array}$ & $\begin{array}{c}2.13 \\
(0.67 \sim 6.82) \\
.201\end{array}$ & $\begin{array}{c}3.80 \\
(2.24 \sim 6.45) \\
<.001\end{array}$ & 1.00 & $\begin{array}{c}2.39 \\
(1.30 \sim 4.38) \\
<.01\end{array}$ & $\begin{array}{c}2.91 \\
(0.49 \sim 17.16) \\
.236\end{array}$ & $\begin{array}{c}3.52 \\
(2.24 \sim 5.54) \\
<.001\end{array}$ \\
\hline Model $2^{*}$ & 1.00 & $\begin{array}{c}3.05 \\
(1.47 \sim 6.35) \\
<.01\end{array}$ & $\begin{array}{c}2.02 \\
(0.61 \sim 6.64) \\
.247\end{array}$ & $\begin{array}{c}4.07 \\
(2.35 \sim 7.04) \\
<.001\end{array}$ & 1.00 & $\begin{array}{c}2.67 \\
(1.46 \sim 4.89) \\
<.01\end{array}$ & $\begin{array}{c}3.13 \\
(0.51 \sim 19.18) \\
.216\end{array}$ & $\begin{array}{c}3.84 \\
(2.39 \sim 6.17) \\
<.001\end{array}$ \\
\hline Model $3^{\S}$ & 1.00 & $\begin{array}{c}3.14 \\
(1.76 \sim 4.14) \\
<.01\end{array}$ & $\begin{array}{c}1.50 \\
(0.60 \sim 2.35) \\
.302\end{array}$ & $\begin{array}{c}6.57 \\
(5.19 \sim 7.27) \\
<.001\end{array}$ & 1.00 & $\begin{array}{c}2.54 \\
(1.38 \sim 4.65) \\
<.01\end{array}$ & $\begin{array}{c}3.40 \\
(0.60 \sim 19.46) \\
.168\end{array}$ & $\begin{array}{c}3.89 \\
(2.41 \sim 6.29) \\
<.001\end{array}$ \\
\hline
\end{tabular}

$\mathrm{SO}=$ sarcopenic-obesity; OR $(95 \% \mathrm{CI})=$ odds ratio $(95 \%$ confidential interval).

${ }^{\dagger}$ Model 1: adjusted age; ${ }^{\dagger}$ Model 2: adjusted age, smoking, alcohol, exercise; ${ }^{\S}$ Model 3: Model $2+$ education, income.

males as 6.57 times (95\% CI: 5.19 7.27, $p<.001)$ and 3.89 times (95\% CI: $2.41 \sim 6.29, p<.001)$ than obesity group respectively, which is higher than Model 1 and 2.

\section{DISCUSSION}

According to normal ageing process, old people have increased body fat and decreased muscle amount. Those two issues make vicious circle, aggravate each other, increase risk of metabolic syndrome, cause long-term hospitalization, increase death rate and become obstacles of healthy ageing. Social and economic burdens resulted from the issues are thought to incur big problems with increase of aged population. Therefore, it is very important to identify effects of sarcopenic obesity on metabolic syndrome and the results can be utilized as important basic materials to develop metabolic syndrome preventive and management strategy to maintain healthy senility.

This study analyzes male and female elderlies in communities using data of Korea National Health and Nutrition Examination Survey. Male and female sarcopenic obesity prevalence were $13.3 \%$ and $22.5 \%$ respectively, which were higher than pure obesity (male $4.5 \%$, female $9.0 \%$ ) or sarcopenia (male $2.0 \%$, female $0.9 \%$ ). Comparing to values in previous studies, these values are similar to the study reporting male $15.4 \%$ and female $22.3 \%$ [6], higher than the study reporting male $6.1 \%$ and female $7.3 \%$ [27] and lower than the study reporting male $35.1 \%$ and female $48.1 \%$ [3]. As diagnosis standards for sarcopenia and obesity are not standardized and different researchers and nations have used different diagnosis standards, difference was shown in prevalence rate. However, considering the trend that ageing population is growing in Korea, sarcopenic obesity in elderlies is an important issue that should not be overlooked. Through further studies in the future, sarcopenic obesity standards appropriate for Koreans should be identified.

When looking into difference in physical composition and individual metabolism index according to the presence of male and female sarcopenia and obesity, both males and females showed the highest total body fat rate and the lowest SMI (\%) in the sarcopenic obesity group, which is consistent with previous studies $[12,17,20]$. The reason why the sarcopenic obesity group showed higher body fat and lower SMI (\%) than pure obesity group is probably because fat infiltrates into abdomen or muscles instead of decreased muscle according to ageing. Additionally, it is known that muscle amount makes effects on basal metabolic rate by $30 \%$, lean body mass would decrease by $3 \%$ annually after 40 , basal metabolic rate would decrease, and in turn body fat would increase [11]. If we cannot disconnect this vicious circle in sarcopenic obesity group, it will aggravate the state of sarcopenia and obesity and many health problems will be incurred. Thus, sarcopenia and obesity are important issues to be managed together. Especially, in sarcopenic obesity group, there was big difference in average body fat rate between males and females (males $29.22 \%$, females $40.27 \%$ ). It is because females redistribute fat tissues to abdomen after menopause and have more fat than males resulted from reduced metabo- 
lism caused by decreased estrogen secretion. Therefore, obesity management of female elderlies is thought to be more important [20].

When looking into difference in individual metabolism index and metabolic syndrome prevalence according to the presence of male and female sarcopenia and obesity, both males and females showed high prevalence of abdominal obesity in sarcopenic obesity group, which is similar to the results of previous studies [3]. Recently, importance of abdominal obesity has been highlighted as etiology of metabolic syndrome, and it is reported that adults with abdominal obesity showed HDL Cholesterol regardless of metabolic syndrome [29]. In this study as well, although it was not statistically significant among females, both males and females showed low HDL Cholesterol in sarcopenic obesity group, which is partially similar to results of previous studies. In other words, decrease in HDL Cholesterol according to abdominal obesity decreases concentration of plasma adiponectin (a kind of protein hormone which involves in glucose regulation and fatty acid oxidation) and may lead to insulin resistance [29]. Therefore, abdominal obesity is a prerequisite reflecting insulin resistance. However, there was no significant difference in high fasting blood glucose in sarcopenic obesity group in both males and females. It is probably because fasting blood glucose is not sufficient to reflect insulin resistance. Recently, Homeostasis Model Assessment of Insulin Resistance $(\mathrm{HOMAIR}=($ fasting insulin $(\mathrm{uIU} / \mathrm{mL}) \times$ fasting plasma glucose $(\mathrm{mmol} / \mathrm{L}) / 22.5)$ has been used, which is an alternative insulin resistance measurement method [19].

Prevalence of metabolic syndrome was shown higher in sarcopenic obesity group as $52.5 \%$ and $60.4 \%$ in males and females respectively, which were the highest values among groups. In a previous study on elderlies over 60 in Korea, it was found to be $60.9 \%$ and $71.1 \%$ in males and females respectively, which were similar to results of this study [12]. However, in a study tracing Mexican elderlies for 8 years, prevalence of metabolic syndrome was higher in obesity group $(37.5 \%)$ than in sarcopenic obesity group $(19.2 \%)$, which is different from the results of this study [7]. It is because prevalence of metabolic syndrome gets different according to abdominal obesity diagnose standards and there are differences in diagnosis standards and cut off points among researches and studies [21], and recently it has been reported that prevalence of obesity, abdominal obesity and metabolic syndrome in Korea is higher than in America or Europe [28]. Additionally, the fact that sarcopenic obesity showed higher prevalence than pure obesity or pure sarcopenia groups can provide an important guideline to select a target group for metabolic syndrome management among elderlies.

When looking into effects of male and female sarcopenic obesity on metabolic syndrome, comparing to normal group, male and female sarcopenic obesity group showed 6.57 times and 3.89 times higher metabolic syndrome cross ratio respectively, which were higher cross ratios obesity than obesity group. It is consistent with Kim and others [6] showing male and female cross ratio as 5.13 times and 3.24 times. Although they did not deal with difference between males and females, a study on Korean elderlies showed 8.28 times higher [3] cross ratio and another study on Taiwanese elderlies showed 11.59 times higher [17] cross ratio, which are higher cross ratio than the result of this study. It is thought because this study used relatively healthy elderlies excluding those with diseases. In another study on 2,943 elderlies over 60 using Korea National Health and Nutrition Examination Survey, sarcopenic obesity group was reported to have higher risk of insulin resistance, metabolic syndrome and cardiovascular disorders [13]. On the other hand, a study on women in menopause [20] reported that sarcopenic obesity group was not related with cardiovascular metabolic syndrome risk factors although this group had higher fat amount and lower lean body mass than other groups. There is a study reporting obesity group has higher risk of metabolic syndrome than sarcopenic obesity group [7], which is not consistent with the result of this study. Stephen and Janssen [30] analyzed risk of cardiovascular disease of obesity groups separating them between with lowered muscle amount and with lowered muscle strength. When muscle amount was used as a standard, incidence of cardiovascular disease increased by $23 \%$ and when muscle strength was used as a standard, it reported that incidence of cardiovascular disease increased by $33 \%$. It reported that muscle strength was more important standard to determine the risk of cardiovascular disease. Recently, researchers introduced new concept of 'dynapenia' for weakened muscle strength distinguishing it from 'sarcopenia' and recommended to use the new concept [10]. Further studies on which of the two from dynapenia and sarcopenia increases risk of metabolic syndrome should be performed in Korea, too. Additionally, it was found that males in sarcopenic obesity have higher risk of metabolic syndrome. It seems because they are exposed to various stresses including smoking and drinking and have higher risk of metabolic syndrome. If it is not managed properly, it may lead to early death and incur social and economic burdens [21]. Thus it should be managed intensively with differentiated strategies. This study is meaningful in that there is no study comparing gender difference on the relationship be- 
tween sarcopenic obesity and metabolic syndrome and continuous repetitive studies are required.

With the trend of health and medical policy being changed from treatment to prevention of diseases, it is very important to prevent metabolic syndrome which may increase risk of various diseases from the perspective of health and economy. To prevent metabolic syndrome, nursing interventions should be developed to manage sarcopenia and obesity together by setting sarcopenic obesity group as a target group.

Restrictions of this study are as follows; first time change should be considered in sarcopenic obesity but this study was a sectional study so there were limitations to address causal effect relationship among variables. Second, sample number of female sarcopenia before weight application was too small and could make effects on study results. Repetitive study in the future with bigger sample size is needed. Nevertheless, this study is meaningful in that it identified difference in effects of sarcopenic obesity on metabolic syndrome according to sex based on Korea National Health and Nutrition Examination Survey results that can represent Korean elderlies, and in that it used relatively healthy elderlies excluding those with diseases to identify pure effects of sarcopenic obesity on metabolic syndrome. It is also meaningful in that it provides basic materials for target group selection and intervention development to prevent metabolic syndrome.

\section{CONCLUSION}

This study is a sectional descriptive study to identify individual metabolism index and prevalence of metabolic syndrome and to identify the effects of sarcopenic obesity on metabolic syndrome of male and female elderlies based on community health survey materials.

According to the results of this study, the ratio of sarcopenic obesity group was the highest in both males and females over 60, and metabolic syndrome prevalence was higher in sarcopenic obesity group than sarcopenia only or obesity only group. Especially, sarcopenic obesity group was found to have higher risk of metabolic syndrome than normal or obesity group and the risk was higher among males than among females.

Through the result of this study it was perceived that sarcopenic obesity of elderlies was an important issue that should not be overlooked. This study provides grounds why differentiated interventions should be provided according to sex by identifying that sarcopenia and obesity are connected in a vicious circle and increase risk of metabolic syndrome. The followings are the proposals based on the result of this study.

First, repetitive studies on effects of sarcopenic obesity of males and females on metabolic syndrome should be made by developing sarcopenic obesity standards appropriate for Koreans.

Second, for sarcopenic obesity candidates, studies developing gender specific metabolic syndrome prevention programs and confirming the application effects should be followed.

Third, studies on the effects of dynapenia and sarcopenia of sarcopenic obesity subjects on metabolic syndrome by distinguishing muscle strength weakness from muscle amount decrease are needed.

Fourth, studies on the effects of sarcopenic obesity on metabolic syndrome according to age are needed.

\section{REFERENCES}

1. Jang HC. Recent progression in sarcopenia and sarcopenic obesity. Journal of the Korean Geriatrics Society. 2011;15(1):1-

7. http://dx.doi.org/10.4235/jkgs.2011.15.1.1

2. Statistics Korea. The prevalence of obesity trend [Internet]. Seoul: Korean Statistical Information Service. 2014 [cited 2016 January 13]. Available from:

http:// kosis.kr/statHtml/statHtml.do?orgId=117\&tblId=DT _11702_N101\&conn_path=I2

3. Lim S, Kim JH, Yoon JW, Kang SM, Choi SH, Park YJ, et al. Sarcopenic obesity: Prevalence and association with metabolic syndrome in the Korean Longitudinal Study on Health and Aging (KLoSHA). Diabetes Care. 2010;33(7);1652-1654.

http://dx.doi.org/10.2337/dc10-0107

4. Park SW. Sarcopenia of the old age. Journal of Korean Endocrine Society. 2007;22(1):1-7.

http://dx.doi.org/10.3803/jkes.2007.22.1.1

5. Baumgartner RN. Body composition in healthy aging. Annals of the New York Academy of Sciences. 2000;904(1):437-448. http://dx.doi.org/10.1111/j.1749-6632.2000.tb06498.x

6. Kim TN, Yang SJ, Yoo HJ, Lim KI, Kang HJ, Song W, et al. Prevalence of sarcopenia and sarcopenic obesity in Korean adults: The Korean sarcopenic obesity study. International Journal of Obesity. 2009;33(8);885-892.

http://dx.doi.org/10.1038/ijo.2009.130

7. Baumgartner RN, Wayne SJ, Waters DL, Janssen I, Gallagher D, Morley JE. Sarcopenic obesity predicts instrumental activities of daily living disability in the elderly. Obesity Research. 2004;12(12):1995-2004.

http://dx.doi.org/10.1038/oby.2004.250

8. Roubenoff R. Sarcopenic obesity: The confluence of two epidemics. Obesity Research. 2004;12(6);887-888.

http://dx.doi.org/10.1038/oby.2004.107 
9. Cauley JA. An overview of sarcopenic obesity. Journal of Clinical Densitometry. 2015;18(4):499-505.

http://dx.doi.org/10.1016/j.jocd.2015.04.013

10. Clark BC, Manini TM. Sarcopenia $\neq$ dynapenia. The Journals of Gerontology Series A: Biological Sciences and Medical Sciences. 2008;63(8):829-834.

11. Hong SM, Choi WH. Clinical and physiopathological mechanism of sarcopenia. The Korean Journal of Medicine. 2012;83(4): 444-454. http://dx.doi.org/10.3904/kjm.2012.83.4.444

12. Chung JY, Kang HT, Lee DC, Lee HR, Lee YJ. Body composition and its association with cardiometabolic risk factors in the elderly: A focus on sarcopenic obesity. Archives of Gerontology and Geriatrics. 2013;56(1):270-278.

http://dx.doi.org/10.1016/j.archger.2012.09.007

13. Zamboni M, Mazzali G, Fantin F, Rossi A, Di Francesco V. Sarcopenic obesity: A new category of obesity in the elderly. Nutrition, Metabolism and Cardiovascular Diseases. 2008;18(5): 388-395. http://dx.doi.org/10.1016/j.numecd.2007.10.002

14. Bouchard DR, Dionne IJ, Brochu M. Sarcopenic/obesity and physical capacity in older men and women: Data from the nutrition as a determinant of successful aging (NuAge)-the Quebec longitudinal study. Obesity. 2009;17(11);2082-2088.

http://dx.doi.org/10.1038/oby.2009.109

15. Villareal DT, Banks M, Siener C, Sinacore DR, Klein S. Physical frailty and body composition in obese elderly men and women. Obesity Research. 2004;12(6):913-920.

http://dx.doi.org/10.1038/oby.2004.111

16. Scott D, Sanders KM, Aitken D, Hayes A, Ebeling PR, Jones G. Sarcopenic obesity and dynapenic obesity: 5 year associations with falls risk in middle aged and older adults. Obesity. 2014; 22(6):1568-1574. http://dx.doi.org/10.1002/oby.20734

17. Lu CW, Yang KC, Chang HH, Lee LT, Chen CY, Huang KC. Sarcopenic obesity is closely associated with metabolic syndrome. Obesity Research \& Clinical Practice. 2013;7(4):e301-e307. http://dx.doi.org/10.1016/j.orcp.2012.02.003

18. Kyle UG, Pirlich M, Lochs H, Schuetz T, Pichard C. Increased length of hospital stay in underweight and overweight patients at hospital admission: A controlled population study. Clinical Nutrition. 2005;24(1):133-142. http://dx.doi.org/10.1016/j.clnu.2004.08.012

19. Lee HW. Diagnosis and treatment of metabolic syndrome. Korean Journal of Medicine. 2006;71(4):463-467.

20. Dos Santos EP, Gadelha AB, Safons MP, Nóbrega OT, Oliveira RJ, Lima RM. Sarcopenia and sarcopenic obesity classifications and cardiometabolic risks in older women. Archives of Gerontology and Geriatrics. 2014;59(1):56-61.

http://dx.doi.org/10.1016/j.archger.2014.03.012

21. Kwon HS, Park YM, Lee HJ, Lee JH, Choi YH, Ko SH, et al.
Prevalence and clinical characteristics of the metabolic syndrome in middle-aged Korean adults. The Korean Journal of Internal Medicine. 2005;20(4):310-316.

http://dx.doi.org/10.3904/kjim.2005.20.4.310

22. Korea Centers for Disease Control and Prevention. Nutrition survey guidelines for the Korea national health and nutrition examination survey IV (2007-2009), V (2010-2012) [Internet]. Seoul: Korea Centers for Disease Control and Prevention. 2016 [cited 2016 April 1]. Available from:

https://knhanes.cdc.go.kr/knhanes/index.do

23. Janssen I, Heymsfield SB, Ross R. Low relative skeletal muscle mass (sarcopenia) in older persons is associated with functional impairment and physical disability. Journal of the American Geriatrics Society. 2002;50(5):889-896.

http://dx.doi.org/ 10.1046/j.1532-5415.2002.50216.x

24. Gallagher D, Heymsfield SB, Heo M, Jebb SA, Murgatroyd PR, Sakamoto $Y$. Healthy percentage body fat ranges: An approach for developing guidelines based on body mass index. The American Journal of Clinical Nutrition. 2000;72(3);694-701.

25. Grundy SM, Cleeman JI, Daniels SR, Donato KA, Eckel RH, Franklin BA, et al. Diagnosis and management of the metabolic syndrome. An American heart association/national heart, lung, and blood institute scientific statement. Circulation. 2005;112(17):2735-2752.

http://dx.doi.org/10.1161/CIRCULATIONAHA.105.169404

26. Lee SY, Park HS, Kim DJ, Han JH, Kim SM, Cho GJ, et al. Appropriate waist circumference cutoff points for central obesity in Korean adults. Diabetes Research and Clinical Practice. 2007;75(1):72-80.

http://dx.doi.org/10.1016/j.diabres.2006.04.013

27. Hwang BK, Lim JY, Lee JY, Choi NK, Ahn YO, Park BJ. Prevalence rate and associated factors of sarcopenic obesity in Korean elderly population. Journal of Korean Medical Science. 2012;27(7):748-755.

http://dx.doi.org/10.3346/jkms.2012.27.7.748

28. Lim J, Kim S, Ke S, Cho B. The prevalence of obesity, abdominal obesity and metabolic syndrome among elderly in general population. Korean Journal of Family Medicine. 2011;32(2):128-134.

http://dx.doi.org/10.4082/kjfm.2011.32.2.128

29. Lee SE, Moon JH, Oh YS, Shinn SH. The association between plasma adiponectin and the components of metabolic syndrome in adults with abdominal obesity. The Korean Journal of Obesity. 2007;16(4):147-153.

30. Stephen WC, Janssen I. Sarcopenic-obesity and cardiovascular disease risk in the elderly. JNHA-The Journal of Nutrition, Health and Aging. 2009;13(5):460-466. http://dx.doi.org/10.1007/s12603-009-0084-z 